\title{
Paracoccidioides brasiliensis: chemical and molecular tools for research on cell walls, antifungals, diagnosis, taxonomy
}

\author{
Gioconda San-Blas · Gustavo Niño-Vega
}

Received: 23 April 2007 / Accepted: 9 July 2007

(C) Springer Science+Business Media B.V. 2007

\begin{abstract}
Paracoccidioides brasiliensis is a dimorphic fungus, a causative agent of paracoccidioidomycosis, one of the most frequent systemic mycoses that affect the rural population in Latin America, only geographical region in which this fungus is to be found. In this work, we discuss matters related to (a) cell wall studies based on the cloning and analysis of genes involved in the synthesis of cell wall components, and their possible roles in virulence and dimorphism in P. brasiliensis, (b) molecular taxonomy and the molecular classification of $P$. brasiliensis as an Ascomycete belonging in the Order Onygenales, (c) phylogeny of $P$. brasiliensis and the possible existence of cryptic species within the genus Paracoccidioides, and (d) new experimental antifungal drugs such as azasterols or sterol hydrazones, compounds that affect the activity of $\Delta^{24(28)}$ sterol methyl reductase (SMR) and/or $\Delta^{(24)}$-sterol methyl transferase (SMT), and (e) specific primers for the molecular detection of $P$. brasiliensis in vitro and in clinical samples.
\end{abstract}

Keywords Antifungals - Cell wall $\cdot$ Molecular diagnosis · Paracoccidioides brasiliensis · Phylogeny · Taxonomy

G. San-Blas $(\bowtie) \cdot$ G. Niño-Vega

Instituto Venezolano de Investigaciones Científicas

(IVIC), Centro de Microbiología y Biología Celular,

P.O. Box 20632, Caracas 1020A, Venezuela

e-mail: sanblasg@ivic.ve; gsanblas@gmail.com

\section{Introduction}

While more than one hundred thousand fungal species are known to this date, only a minority is responsible for causing disease in mammals and, particularly, in humans. In them, morphogenetic transitions are frequently required to express a certain degree of virulence. Notable among these important pathogens are Candida albicans or some species of Aspergillus, whose morphogenetic processes are the subject of intense studies [1, 2]. Another fungal species among this group of pathogens is Paracoccidioides brasiliensis, a dimorphic fungus, the causative agent of paracoccidioidomycosis (PCM), one of the most frequent systemic mycoses affecting the rural population of Latin America, the only geographic region in which PCM is found [3-5]. Its dimorphic transition is dependent on temperature, a yeastlike (Y) form being observed at $37^{\circ} \mathrm{C}$ and a mycelial (M) one at $23^{\circ} \mathrm{C}$ [3]. Such a sudden environmental change at the moment of infection implies the ability to rapidly adjust in order to survive and invade the host. As particular features of the morphogenetic process in fungi, (a) it is reversible, (b) it is not a vital component of the fungal life cycle but rather an opportunistic adaptation to environmental conditions and (c) the conversion to a different form (frequently, the Y phase) is a requisite for progressive infection [6]. Such process is linked to the induction of specific gene products, through biochemical pathways that modulate the synthesis of 
different compounds, which in turn, affect the final form of the cell.

\section{Paracoccidioides brasiliensis and its cell wall}

The fungal cell wall, an extracellular matrix containing polysaccharide-protein complexes, is an everchanging structure whose composition and structural organization is regulated during the cell cycle and in response to changing environmental conditions and stress $[7,8]$. Chitin and $\beta$-1,3-glucan represent the main structural components of fungal cell walls [9]. These polysaccharides oppose the positive turgor pressure within the cell and ultimately determine its morphology $[7,10]$. The lack of chitin and $\beta-1,3-$ glucan in mammals and the fact that they are essential for fungi, make their synthesis potential targets for the development of antifungal drugs [11, 12].

The biochemical and molecular mechanisms controlling the dimorphic process in P. brasiliensis has been a long-featured subject of research. Changes in $\mathrm{Y}$ and $\mathrm{M}$ wall structures were reported, as early as 1969 [13, 14], while the proposal of $\alpha$-1,3-glucan as both dimorphic determinant and virulence factor [15] was first reported in this fungus. This neutral polysaccharide is present in the cell wall of the pathogenic $P$. brasiliensis $\mathrm{Y}$ phase, but disappears when the fungus changes to its $\mathrm{M}$ phase, to be totally substituted by $\beta$-1,3-glucan in the latter [14]. Chitin is the third polysaccharide conforming $P$. brasiliensis cell walls in both the $\mathrm{M}$ and $\mathrm{Y}$ phases [for a review, see 6]. While $\beta$-1,3-glucan and chitin are recurrent cell wall polysaccharides in the Kingdom Fungi [9], $\alpha$-1,3-glucan is a rather infrequent occurrence. Besides $P$. brasiliensis, it has been reported in Schizosaccharomyces pombe [16], Aspergillus nidulans [17], Aspergillus niger [18], Aspergillus fumigatus [19], Cryptococcus neoformans [20], Histoplasma capsulatum [21], and Blastomyces dermatitidis [22], among a few others. A partial chemical structure was reported long ago in P. brasiliensis $\alpha$-1,3-glucan [14]. According to these authors, this polysaccharide was constituted by a lineal stretch of 53 units of 1,3-linked disaccharides plus three disaccharides in undefined 1,4 or 1,6-links. Finally, a branching point (undefined type of link) assembled two chains of linear polysaccharide, to a final length of approximately 224 glucose units. This arrange- ment resembles that reported for pseudonigeran in $A$. niger [18]. More than 30 years later, Grün et al. [23] detailed the chemical structure of $S$. pombe $\alpha$-1,3-glucan. It shows remarkable resemblance to the one reported by Kanetsuna et al. [14] for P. brasiliensis, that is, $S$. pombe $\alpha-1,3$-glucan was found to consist of a single population of linear glucose polymers, approximately 260 residues in length. These glucose polymers were composed of two interconnected linear chains, each consisting of approximately 120 (1->3)-linked $\alpha$-D-glucose residues and some (1->4)linked $\alpha$-D-glucose residues at the reducing end.

$S$. pombe also served as vehicle to identify and analyse the first $\alpha$-1,3-glucan synthase-encoding gene, named ags1 [24]. In the genome sequence of $S$. pombe, four additional $\alpha-1,3$-glucan synthaseencoding genes have been described [25]. The genes of this family, ags 1/mok 1 and mok11-mok14, encode large, multi-domain proteins consisting of approximately 2,400 amino acids, except for mok14, which encodes a shorter protein lacking the $\mathrm{NH}_{2}$-terminal domain.

Damvel et al. [26] identified a family of five $\alpha-1,3-$ glucan synthase-encoding genes in $A$. niger and three in Penicillium chrysogenum. Once sequenced, the predicted protein sequence of the ags $A$ gene indicated that the overall domain structure of $\alpha-1,3$-glucan synthases is conserved in fungi. The amino acid sequence of AbAgsA revealed a similar multi-domain organization of the protein as previously described for the Ags1 protein of S. pombe [24]. The different domains of the $\alpha$-1,3-glucan synthases are predicted to be involved in synthesis, transport and coupling of two $\alpha$-glucan chains by a transglycosylation activity to create mature cell wall $\alpha$-glucan [23-25].

The $\alpha$-glucan synthase gene of $P$. brasiliensis (PbrAGS), has been cloned in our laboratory [NiñoVega et al. unpublished results, GenBank accession number AY780573]. Analysis of its sequence suggests a resemblance to previously reported fungal $A G S[24,26]$. As with other $\alpha$-glucan synthases, three distinct domains can be identified in the PbrAgs1 sequence. The first domain-located extracellularly, according to computer models-shows significant sequence similarities to $\alpha$-amylases belonging to family 13 of the glycosyl hydrolases [27] and is denoted as an amylase homologous domain (AHD). In other fungi, it has been suggested that this domain is involved in a transglycosylation activity, joining 
two chains of $\alpha$-1,3-glucan through an $\alpha-1,4$ link [23]. The second domain is bordered by two hydrophobic sequences. It is predicted to be intracellular and contains a glycogen or starch synthase homologous domain (G/SSHD). Therefore, it is likely that it encodes the glucan synthase domain of PbrAgs1. The third domain is predicted to span the membrane 8 times. This multi-pass transmembrane region (MTM) is thought to be involved in the transport of the $\alpha$-glucan chain across the plasma membrane [24]. In accordance with the presence of $\alpha-1,3$-glucan exclusively in the $\mathrm{Y}$ phase of the fungus, Northern analysis show that the PbrAGS1 gene is only expressed in the $\mathrm{Y}$ phase of $P$. brasiliensis [NiñoVega et al. unpublished results].

Chitin synthesis in fungi is a rather complex process, regulated by multigene families encoding chitin synthase isoenzymes, some of them redundant, whose activities may be spatially ordered and otherwise strictly regulated to bring about the fulfillment of the several roles ascribed to them. Based on differences in regions of high sequence conservation, chitin synthases have been organized into seven classes within two domains, whose functional implications are not yet clear in all cases [28-30]. Six chitin synthase genes, representing different classes of enzyme ( $\mathrm{PbrCHS} 1$ in class I, PbrCHS2 in class II, $\mathrm{PbrCHS} 3$ in class IV, PbrCHS4 in class VII, PbrCHS5 in class $\mathrm{V}$ and PbCHS6 in class VI) are active in $P$. brasiliensis [29, 31-33]; they help in the synthesis of chitin in amounts that comprise $43 \%$ of the dry weight of the wall of the pathogenic Y form and $13 \%$ of the $M$ cell wall [34].

Expression of $P$. brasiliensis chitin synthase genes throughout the dimorphic shift was explored [32]. PbrCHS1 and PbrCHS2 have similar transcript sizes at around $3.7 \mathrm{~kb}$, while large transcripts of about $6.5 \mathrm{~kb}$ and $6.7 \mathrm{~kb}$ were observed for PbrCHS4 and PbrCHS5, respectively. The structures of the latter are similar to cmsA from A. nidulans [29, 32], which has been proposed as a chitin synthase coupled to a myosin motor-like region. In association with cytoskeletal structures, the myosin region might translocate the newly synthesized chitin molecules to its site of deposition. However, PbrChs4p does not possess the P-loop, switch I and switch II domains present in CsmA and conserved among the myosins, a fact that led us to propose a new Class VII to group several chitin synthases with incomplete myosin-motors [29].
Transcripts from these four $\mathrm{PbrCHS}$ genes were detected in both $\mathrm{Y}$ and $\mathrm{M}$ morphotypes, exhibiting similar patterns of expression through the $\mathrm{M}$ to $\mathrm{Y}$ transition, with a preferential expression in the $M$ form. This result was unexpected, since it is the $\mathrm{Y}$ form of the organism and not the $\mathrm{M}$ phase the one containing a three-times higher chitin content [34]. Of the six chitin synthase genes reported in P. brasiliensis so far, PbrCHS3 is the only one exclusively expressed in the pathogenic $\mathrm{Y}$ form of the fungus [Niño-Vega et al. unpublished results], making this an interesting gene for exploring its function.

\section{Fungal taxonomy}

In classic systematics, $P$. brasiliensis has been classified as an imperfect fungus, in the artificial group of the anamorphic phylum Deuteromycota, class Hyphomycetes, in view of the fact that so far, no sexual structures have been described in this fungus. Molecular methodologies based on epidemiological typing and population genetics, such as caryotyping, multilocus enzyme electrophoresis, RAPD, RFLP, among others [3], bring forward taxonomic proposals to otherwise unclassified species.

Phylogenetic comparisons of dermatophytes and dimorphic fungi, based on the rDNA 28S ribosomal subunit [35] place $P$. brasiliensis in the order Onygenales, family Onygenaceae (phylum Ascomycota), together with $B$. dermatitidis, $H$. capsulatum and $H$. capsulatum var. duboisii, whose teleomorphs belong in the genus Ajellomyces. The phylogenetic relationship between $P$. brasiliensis and $H$. capsulatum was demonstrated once more in the tree generated with sequences of deduced aminoacids from fungal actins taken from the GenBank to which the sequence deduced from PbrACTl was added [36]. In such a tree (Fig. 1), P. brasiliensis is close to $H$. capsulatum, another pathogenic dimorphic fungus whose teleomorph, Ajellomyces capsulatus, has been classified by means of classic taxonomic criteria, as belonging to the order Onygenales, family Onygenaceae [37]. With similar technique, we also compared the $P$. brasiliensis $O D C$ gene with other fungal $O D C$ genes $[38,39]$. The generated dendrogram placed $P$. brasiliensis in the vicinity of Coccidioides immitis, another important fungal 


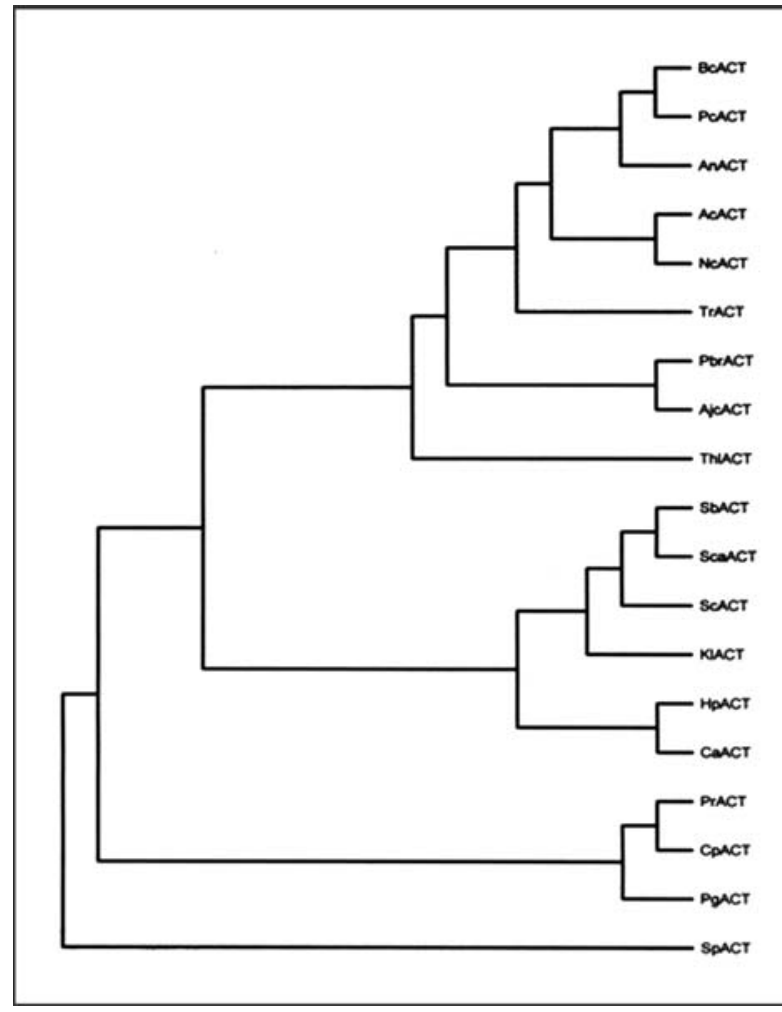

Fig. 1 Phylogenetic tree of actin genes, maximum parsimony. Abbreviations: Acremonium chrysogenum (Ac), Hansenula polymorpha $(\mathrm{Hp})$, Botrytis cinerea $(\mathrm{Bc})$, Kluyveromyces lactis (Kl), Penicillium chrysogenum $(\mathrm{Pc})$, Phaffia rhodozyma $(\mathrm{Pr})$, Puccinia graminis (Pg), Histoplasma capsulatum (Hc), Candida albicans $(\mathrm{Ca})$, Cryptosporidium parvum $(\mathrm{Cp})$, Neurospora

dimorphic pathogen of unknown teleomorph, whose placement, as Onygenal has been confirmed by molecular methods [40, 41]. Therefore, our results coincide with previous phylogenetic trees generated from the large rRNA 28S subunit [35], 18S rRNA [42] and the ITS (internally transcribed spacer) region [41], all of them placing $P$. brasiliensis in the vicinity of $C$. immitis and $H$. capsulatum, within the phylum Ascomycota, order Onygenales, family Onygenaceae [3].

A chemical approach to the fungal classification of mitosporic fungi has been developed by Leal et al. [43], as complementary to the molecular methods. The fine structure of the soluble polysaccharide F1SS, a minor component of the fungal cell wall, has served as the substrate for a proposal in which the evolutionary character of F1SS has consequences in fungal taxonomy [44], giving rise to a useful tool for the definition of certain genera and the determination
Botsytis cinerea

Penicillium chrysogenum

Emericella nidulans

Acremonium chrysogenum

Neurospora crassa

Ascomycota Helotiales

Ascomycota Eurotiales

Trichoderma reesei

Paracoccidioides brasiliensis

Histoplama capsulatum

Thesmomyers lonuginosus

Saccharomyces bayanus

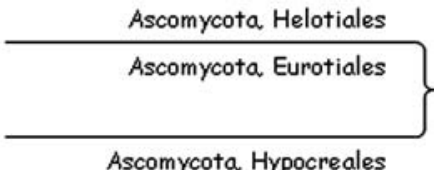

Saccharomyers carlbengensis

Sacharomyers cerevisias

Kluyveromyes lactis

Hansenula polymospha

Condida albicans

Phaf fia shodo zyma

Cryptosporidium parvum

Putcinia graminis

Bosidiomycota, Cystofilobasidiales

Protozoa, Coccidia Cryptosporidiae

Basidiomycota, Uredinales

Schizosaceharomyeres pombe

Ascomycota Schizosaccharomycetales

crassa (Nc), Thermomyces lanoginosus (Tl), Trichoderma reesei (Tr), Emericella nidulans (An), Saccharomyces carlbergensis (Sca), Schizosaccharomyces pombe (Sp), Saccharomyces bayanus (Sb), Saccharomyces cerevisiae (Sc) [36]. Reproduced by permission

of phylogenetic relationships in fungi. The fine structure of $P$. brasiliensis cell wall galactomannan (F1SS) in both morphological phases was studied by nuclear magnetic resonance $\left({ }^{1} \mathrm{H}-\mathrm{NMR}\right.$ and ${ }^{13} \mathrm{C}$ NMR) [45, 46]. From these analyses, it was deduced (Fig. 2) that the galactomannan from the $M$ phase of $P$. brasiliensis consisted of a repetitive trisaccharidic unit $[\rightarrow 6)-[\alpha$-D-Galf-(1 $\rightarrow 6)-\alpha$-D-Man $p-(1 \rightarrow 2)]-\alpha-$ D-Manp- $(1 \rightarrow]$, while the polysaccharide from the Y phase was conformed by a repetitive disaccharidic unit [6)- $\alpha$-D-Manp-(1 $\rightarrow 2)-\alpha$-D-Man $p-(1 \rightarrow]$, alternating with a trisaccharidic unit $[\rightarrow 6)-[\beta$-D-Galf$(1 \rightarrow 6)-\alpha$-D-Manp- $(1 \rightarrow 2)]$ - $\alpha$-D-Manp- $(1 \rightarrow]$. As seen in Fig. 2, some sequences (A, B and C) are shared by both galactomannans, while sequences $\mathrm{D}$ and $\mathrm{E}$ are present only in the yeastlike phase.

In most Onygenales, F1SS are composed by a chain of mannose units linked by $(1 \rightarrow 6)$ bonds, with occasional groups substituted with a single residue or 
Fig. 2 Structures deduced for cell wall F1SS polysaccharides from P. brasiliensis (M form), A. terreus, A. alveolata and $O$. equina $[45,46]$. Reproduced by permission from Taylor \& Francis Ltd., http:// www.informaworld.com

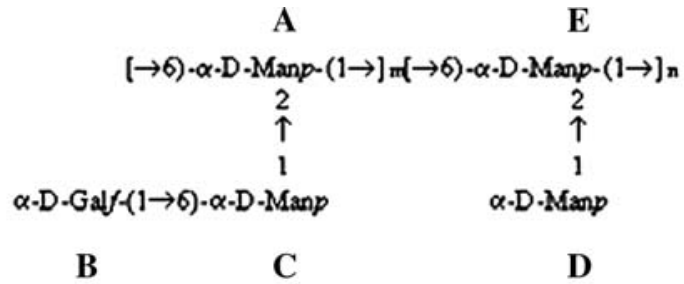

P. brasiliensis: $\mathrm{m} \sim 27$ and $\mathrm{n} \sim 3$ : A. terreus: $\mathrm{m} \sim 21$ and $\mathrm{n} \sim 19:$. A. alwolata: $\mathrm{m}$ $\sim 15$ and $n \sim 25$; 0 . equina: $m \sim 10$ and $n \sim 34$. short chains of diverse sugars [43]. P. brasiliensis F1SS shares such features together with F1SS from fungi belonging to the family Onygenaceae, such as Ascocalvatia alveolata, Aphanoascus terreus and Onygena equina, giving further support to the proposed classification of $P$. brasiliensis within this family $[45,46]$.

\section{Molecular phylogeny}

Molecular genetics and cladistic analyses provide a method to separate species under the evolutionary species concept, using an operational method known as phylogenetic species recognition (PSR), which, when coupled to genealogical concordance (GCPSR), is capable of detecting isolated groups by comparing gene trees from a number of loci [47, 48]. GCPSR has been useful in the recent split of $C$. immitis, a seemingly uniform species by phenotypic criteria, into two species: $C$. immitis (Californian isolates) and C. posadasii (non-Californian isolates) [47], and the recognition of 8 distinct phylogenetic species within the genus Histoplasma, out of the three phenotypic varieties previously acknowledged [49].

Previous RAPD analyses [50-52], RFLP [53], and partial sequences of some genes [54, 55] from several $P$. brasiliensis isolates, revealed genetic variability and clusters correlated with geography $[50,53]$ or virulence $[51,56]$. Based on phylogenetic analysis of 65 P. brasiliensis isolates, Matute et al. [57] recently proposed three distinct phylogenetic species within P. brasiliensis: S1 (a paraphyletic group formed by 38 isolates of Argentinean, Brazilian, Peruvian and Venezuelan origins, plus an isolate from an Antarctic penguin), PS2 (six isolates, five of them of Brazilian origin, and one Venezuelan) and PS3 (21 Colombian isolates).
Following this line of research, we analyzed the phylogenetic relationship of coding and non-coding regions of various genes (CHS4, Actin, ODC, URA3, CHS2, HSP70, FKS1, Hidrophobin, Kex1, Catalase A, Catalase P, Formamidase, Glyoxalase and ITS) in $21 P$. brasiliensis isolates, 9 of which had not been included in the previous study [57]. Our results [Carrero et al. submitted] indicated that a particular isolate $(\mathrm{Pb01})$ was basal and distant to all other isolates. Moreover, the genetic variation in coding regions of $P$. brasiliensis indicates that there may be more than the three phylogenetic species already reported in the morphological species $P$. brasiliensis [57]. Strain $\mathrm{Pb} 01$ is of interest, because this particular isolate is so far, the best studied isolate from a molecular point of view, as deduced from a thorough analysis of its transcriptome, that yielded 6,022 assembled groups from mycelium and yeast phase expressed sequence tags, covering about $80 \%$ of the estimated $P$. brasiliensis $\mathrm{Pb} 01$ genome [58]. The results above may lead us to speculate that $\mathrm{Pb} 01$ might be a new species within the genus Paracoccidioides. However, establishing if $\mathrm{Pb} 01$ is phylogenetically a different species would require the finding of several new Pb01-like isolates to validate this hypothesis. Ongoing work will help elucidate this point [Felipe et al. unpublished results].

\section{Experimental antifungals}

New drugs that interfere the metabolic pathway to membrane sterols

The treatment of PCM is lengthy, starting with an aggressive dosage of antifungal agents, to which a maintenance treatment follows for months or years [5]. Sulfonamides (either sulfamethoxazole or 
sulfadiazine), later complemented with the addition of trimethoprim, were introduced several decades ago for PCM treatment. Although this combination of drugs is inexpensive and usually effective in the treatment of PCM, it is a lengthy procedure that often discourages patients for a follow-up treatment.

Amphotericin B was first used for the treatment of PCM in 1958. It binds to sterols, preferentially to the primary fungal cell membrane sterol, ergosterol. This binding disrupts osmotic integrity of the fungal membrane, compromising its barrier function in such a way that leakage of intracellular potassium, magnesium, sugars, metabolites and cellular death proceed. This drug is only to be administered intravenously, under strictly regulated conditions, and with a continuous surveillance of eventual renal impairment in the patient, because of its serious side effects as a nephrotoxic agent [5]. Over the years, $P$. brasiliensis isolates have continued to be sensitive to amphotericin $\mathrm{B}$, thereby being the drug of choice when treatment with other antifungal agents becomes ineffective because of resistance.

The introduction of azoles marked an advance in the treatment of fungal diseases, PCM among them. Azoles act on ergosterol biosynthesis at the C-14demethylation stage, a three step, oxidative reaction catalyzed by the cytochrome P-450 enzyme $14 \alpha-$ sterol demethylase. The resulting ergosterol depletion and accumulation of 14-methylated sterols interferes with the functions of ergosterols as a membrane component, altering the normal permeability and fluidity of the fungal membrane, with secondary consequences for membrane-bound enzymes, such as those involved in cell wall synthesis [12]. Imidazoles (ketoconazole) and triazoles (fluconazole, saperconazole, and particularly itraconazole) have been extensively used for the treatment of PCM. They are highly active against in vitro cultures of P. brasiliensis; resistant isolates have been detected occasionally. Azoles have proven effective for clinical purposes, showing fewer side effects than amphotericin B. Most patients are treated for 2-12 months, with few relapses [for a review, see 59].

The above mentioned antifungal antibiotics have drawbacks such as long time of medication (particularly, sulfa derivatives), severe renal side effects (amphotericin B) or other side effects, emergence of resistance (all antifungals), and high cost (azoles, allilamines, lipid formulations of amphotericin B). Therefore, the search for new and more effective chemotherapeutic agents against $P$. brasiliensis and other fungal pathogenic species, with fewer or no side effects, continues. To this effect, the rational design of new experimental antibiotics becomes an important tool to approach such search.

The metabolic pathway to membrane sterols is blocked by allilamines (by inhibition of the squalene epoxidase) or azoles (by inhibition of the cytochrome P-450 enzyme $14 \alpha$-sterol demethylase). Both mechanisms are common to the fungal pathogen and the host and consequently, drugs that interfere with them affect selectivity towards the pathogen, hence their undesirable side effects. However, differences exist in primary metabolism between mammals and other eukaryotes such as plants, fungi and protozoa [59]. While mammals synthesize $\mathrm{C}_{27}$ cholestane-based members of the steroid family, pathogenic fungi, protozoa and plants require the presence of endogenous sterols $\mathrm{C}_{28}-\mathrm{C}_{29}$ (typically ergosterol and 24-alkyl analogs) which act as essential growth factors for these organisms. The enzyme responsible for the addition of these alkyl groups to carbon C-24 and for the regulation of carbon flow in the sterol pathway is the $\Delta^{(24)}$-sterol methyl transferase (SMT) [59, 60]. With this in mind, new compounds were synthesized. Three of them were azasterol derivatives, i.e., 20-piperidyl-2-yl$5 \alpha$-pregnan-3 $\beta, 20(\mathrm{R})$-diol $(22,26$-azasterol or AZA1), 22-piperidin-2-yl-pregnan-22(S),3 $\beta$-diol (AZA2) and 22-piperidin-3-yl-pregnan-22(S),3 $\beta$-diol (AZA3) (Fig. 3a) [60]; additionally four sterol hydrazones, namely, 20-hydrazone-imidazolin-2-yl-5 $\alpha$-pregnan$3 \beta$-ol (H1), 20-hydrazone-pyridin-2-yl-5 $\alpha$-pregnan-3 $\beta$-ol (H2), 22-hydrazone-imidazolin-2-yl-chol-5-ene-3 $\beta$ ol (H3) and 22-hydrazone-pyridin-2-yl-chol-5-ene$3 \beta$-ol (H4) were also tested [Visbal et al. manuscript under preparation]. AZA-1 $(0.1-5 \mu \mathrm{M})$ inhibited $P$. brasiliensis growth in a dose-dependent fashion, reaching $100 \%$ growth arrest at the latter concentration and above [60], a result that is similar to those previously reported for parasites (Trypanosoma cruzi, Leishmania donovani) [61] and fungi (Pneumocystis carinii) [62]. AZA-2, instead, was only able to inhibit $60 \%$ growth at the highest concentration used in these experiments $(10 \mu \mathrm{M})$, while AZA-3 was the most powerful drug, since a concentration of $0.5 \mu \mathrm{M}$ was able to completely inhibit fungal growth in a fungicydal manner [60]. 
a
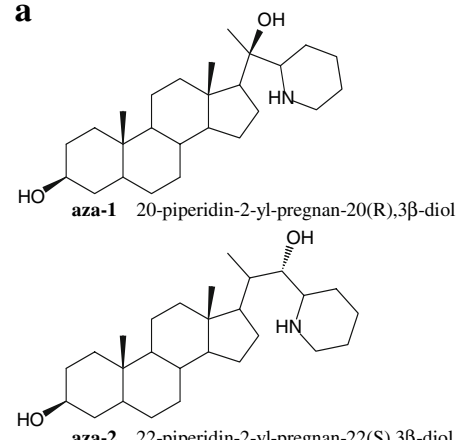

aza-2 22-piperidin-2-yl-pregnan-22(S),3ß-diol

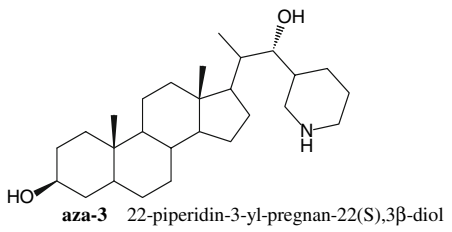

Fig. 3 (a) Chemical structures of 20-piperidyl-2-yl-5 $\alpha$-pregnan-3 $\beta, 20(\mathrm{R})$-diol (22,26-azasterol or AZA-1), 22-piperidin-2yl-pregnan-22(S),3 $\beta$-diol (AZA2) and 22-piperidin-3-yl-pregnan-22(S),3 $\beta$-diol (AZA3) [60]. (b) Molecular electrostatic potential mapped over the electronic charge iso-density surface

In order to explore their possible mechanism(s) of action, a detailed analysis of the sterol composition of $P$. brasiliensis ( $\mathrm{Y}$ phase) grown in the absence or presence of subinhibitory concentrations of the three azasterols analogs $(1 \mu \mathrm{M}$ (AZA-1), $2 \mu \mathrm{M}$ (AZA-2), and $0.3 \mu \mathrm{M}$ (AZA-3)), was carried out (Table 1) [60]. In control cells, main sterols were brassicasterol $(\mathrm{G})$ $(69.1 \%)$, ergosterol (F) (26.8\%) and lanosterol (A) $(4.1 \%)$, as reported before [63]. On exposure to AZA-1, ergosta-5,7,24(28)-trien-3 $\beta$-ol ( $\left.\mathrm{D}^{\prime}\right)(17.1 \%)$ and lanosterol (A) (11\%) accumulated, while AZA-2 led to an important accumulation of ergosta$5,7,22,24(28)$-tetraen-3 $\beta$-ol (E) (50.5\%). With AZA3 , instead, an important accumulation of lanosterol (A) $(34.5 \%)$ was observed. Concurrent with the accumulation of these intermediates, final products of the sterol pathway (brassicasterol and ergosterol; G and F, respectively) decreased substantially (Table 1 ). Such dissimilar lipid profiles suggest diverse effects of each individual azasterol on the sterol biosynthetic pathway. As mentioned above, P. brasiliensis (Y phase) was susceptible to the action of azasterols in the sequence: AZA-3 > AZA-1 > AZA-2. The accumulation of ergosta-5,7,24(28)-trien-3 $\beta$-ol (D') and ergosta-5,7,22,24(28)-tetraen-3 $\beta$-ol (E) in cells treated with AZA-1 and AZA-2, respectively, suggest that both AZA-1 and AZA-2 significantly inhibit the $\Delta^{24(28)}$ sterol methyl reductase (SMR), an enzyme that catalyzes the saturation of the $\Delta^{24(28)}$ double bond in the biosynthesis of brassicasterol. However, their actions were slightly different. AZA-1 impaired both SMR activity and the introduction of the $\Delta^{22}$ bond in the sterol side chain, in agreement with previous studies [61, 62]. On the other hand, AZA-2 was much more selective as a SMR inhibitor, due to the accumulation of ergosta-5,7,22,24(28)-tetraen-3 $\beta$-ol (E); no interference with the metabolic transformation of the B-C ring system and side chain of the sterol molecule occurred with this azasterol analogue. Additionally, a modest accumulation of lanosterol (A) suggested that SMT was also slightly affected by AZA-1. AZA-3, instead, produced a major antiproliferative effect on $P$. brasiliensis, by inhibiting SMT, as deduced from the important accumulation of lanosterol recorded in this case. With regards to the sterol hydrazones, $\mathrm{H} 1, \mathrm{H} 2$ and $\mathrm{H} 3$ inhibited SMT, in a manner dependent on the stereochemical location of the hydrazone group. H4, instead, induced a good antiproliferative activity not associated with blockage of any step in the pathway to sterol biosynthesis, suggesting a different mode of action [Visbal et al. manuscript under preparation]. 
Table 1 Sterols in P. brasiliensis, Y phase, grown in the presence or absence of azasterols

\begin{tabular}{|c|c|c|c|c|c|}
\hline \multirow[t]{2}{*}{ Compound } & Retention time (min) & Control & $\begin{array}{l}\text { AZA-1 } \\
1 \mu \mathrm{M}\end{array}$ & $\begin{array}{l}\text { AZA-2 } \\
2 \mu \mathrm{M}\end{array}$ & $\begin{array}{l}\text { AZA-3 } \\
1 \mu \mathrm{M}\end{array}$ \\
\hline & 17.6 & 69.1 & 54.7 & 13.5 & 39.8 \\
\hline & 18.0 & 0.0 & 0.0 & 23.5 & 0.0 \\
\hline & 18.2 & 26.8 & 17.4 & 0.0 & 9.1 \\
\hline & 18.5 & 0.0 & 17.1 & 0.0 & 0.0 \\
\hline & 18.5 & 0.0 & 0.0 & 50.5 & 0.0 \\
\hline & 19.2 & 0.0 & 0.0 & 0.0 & 0.0 \\
\hline & 19.9 & 0.0 & 0.0 & 0.0 & 0.0 \\
\hline & 20.5 & 4.1 & 10.8 & 8.2 & 48.9 \\
\hline & 21.3 & 0.0 & 0.0 & 4.2 & 2.2 \\
\hline & Not detected & & & & \\
\hline & Not detected & & & & \\
\hline
\end{tabular}

Numbers in bold correspond to significant values discussed in the text 60] 
In order to develop rational criteria for the development of antifungals, molecular modeling is used to study the molecular conformation in solution of drug candidates, by means of the molecular electrostatic potential (MEP), obtained from Quantum Mechanical $a b$ initio calculations. Such approach has been used with azasterols (Fig. 3b). No significant differences in electrostatic potential among the nitrogen atoms or its closest hydroxyl group of each azasterols were found. MEP in azasterols provide a useful guide to the molecular interactions in the active site of SMT. It seems likely that the inhibitor's negative charge (provided by the lone electron pair in the $\mathrm{N}$ atom) will be in close contact with the S-adenosyl methionine [AdoMet] positive charge (generated by the sulphur atom). On the other hand, the molecular conformation of the piperidine side chain of AZA1 is such that the $\mathrm{N}$ atom in the $\beta$ plane of the sterol nucleus has the $\mathrm{N}$ lone pair in axial position, emerging almost parallel to the plane, pointing away from the molecular plane of the sterol nucleus. This conformation probably orientates AZA1 N lone pair in such a way that it inhibits SMT by strongly interacting with the enzyme from the right side of its active site. The different conformations in the piperidine rings of AZA2 and AZA3 are due to the absolute configuration of the hydroxyl group (S) in C-22 [59]. In AZA2, the $\mathrm{N}$ atom is in the sterol plane, and its lone pair is oriented toward the sterol nucleus, configuration that greatly decreases AZA2-SMT interaction by effect of the steric hindrance produced by the piperidine ring. This effect was also observed in N-methyl-22,26-azasterol. In this molecule, a $\mathrm{N}$ methyl group forces an orientation of the $\mathrm{N}$ lone pair toward the sterol nucleus. Such structural characteristic seems appropriate to inhibit SMR but not SMT. Contrary to AZA1, AZA3 has a more favourable conformation of the $\mathrm{N}$ atom, inasmuch as its lone pair is in an axial position opposite to the sterol nucleus. This allows a stronger interaction with the positive charge in the active site of SMT. When a comparison is made between the $\beta$-orientation of the lanosterol side chain and the equivalent one of AZA3, one finds that the $\mathrm{N}$ lone pair has a similar orientation in the space as the $\pi$-orbitals of the $\Delta^{24}$-bond of lanosterol [59].
Drugs that interfere with the synthesis of cell wall $\beta$-1,3-glucan

As mentioned in a previous section, the lack of chitin and $\beta$-1,3-glucan in mammals and the fact that their presence in the fungal cell wall is essential for survival of the microorganism, make their synthesis potential targets for the development of highly specific antifungal drugs [11, 12]. Special interest has been drawn to the development of antifungal antibiotics that block the synthesis of cell wall glucan. Echinocandins, such as micafungin (Mycamine $\mathbb{R}$; Astellas Pharma) or caspofungin (Cancidas (R); Merck) have been recently incorporated, albeit under restricted conditions, as part of the clinical armamentarium for the treatment of candidiasis or aspergillosis refractive to more conventional antifungals, because of the low minimal inhibitory concentrations (MICs) usually displayed by these compounds against those fungal species. These drugs target the enzyme $\beta$ - D 1,3-D-glucan synthase, the activity of which is essential for the assembly of a functional cell wall in many fungi, as far as the synthesis of fungal $\beta$-1,3-glucan is concerned [12]. Limited in vitro studies indicate that echinocandins have high MICs for zygomycetes, Fusarium spp., and Cryptococcus neoformans [64]. MICs for caspofungin in the pathogenic yeastlike phases of several dimorphic fungi, fluctuate according to species and strains within species, e.g., B. dermatitidis $(0.5-8 \mu \mathrm{g} /$ $\mathrm{ml})$ or $H$. capsulatum $(<0.125 \mu \mathrm{g} / \mathrm{ml} ; 0.5-4 \mu \mathrm{g} / \mathrm{ml})$ [65]. On the other hand, values for Candida, a socalled caspofungin-sensitive genus, also shows ranges of action, e.g., C. albicans $(0.03->16 \mu \mathrm{g} / \mathrm{ml})$, C. krusei $(0.03-2 \mu \mathrm{g} / \mathrm{ml})$, C. glabrata $(0.03-2 \mu \mathrm{g} /$ $\mathrm{ml})$, C. tropicalis $(0.06-1 \mu \mathrm{g} / \mathrm{ml})$, or $C$. parapsilosis $(0.5-16 \mu \mathrm{g} / \mathrm{ml})$ [66]. As deduced by a large-scale study carried out simultaneously in 17 American and European laboratories, under strictly controlled identical conditions [67], considerable interlaboratory variability of MIC data on caspofungin are found when testing Candida and Aspergillus isolates, results that suggest the need for careful interpretation of the antifungal effect of this drug.

P. brasiliensis has been reported as resistant to the action of micafungin [68] inasmuch as MIC in seven strains ranged between 4 and $16 \mu \mathrm{g} / \mathrm{ml}$ for the $\mathrm{M}$ phase and $>64 \mu \mathrm{g} / \mathrm{ml}$ for $\mathrm{Y}$ cells of the fungus. These results demonstrated that the antifungal activity of 
micafungin depended on the growth form, and particularly on the cell wall structure of each morphotype which, as mentioned before, is conformed by $\beta$-1,3-glucan -the target of the candin class of compounds- as the sole neutral polysaccharide of the $\mathrm{M}$ phase, being substituted by $\alpha-1,3$-glucan in the $\mathrm{Y}$ phase. Preliminary studies in our laboratory confirm a higher resistance of the pathogenic Y cells when compared to $\mathrm{M}$ cultures, but also indicate that the susceptibility of $P$. brasiliensis to caspofungin depends on the strains.

\section{Molecular diagnosis}

Molecular methods of fungal identification and diagnosis (mainly, PCR, alone or in combination with more sophisticated methodologies) are being incorporated into the routine of the clinical laboratory, to increase the efficacy of current microbiologic and immunologic methods. Traditional methods for PCM diagnosis have usually relied on the microscopic identification of $P$. brasiliensis and on serologic diagnostics that depend on antibodies, among them, gp43, currently the reference antibody for PCM [3]. Drawbacks exist, though. Gp43 may disappear from circulation during treatment [69], or generate false negatives [70] and occasional cross-reactions [71], probably due to gp43 polymorphism [55]. Therefore, molecular methods are being developed to help in the diagnosis of PCM. ITS [72] or gp43 [73] regions have been used in the design of specific primers for the identification of $P$. brasiliensis, either in cultures or clinical samples from PCM patients [73].

In our laboratory, we have developed a molecular diagnostic method based on two fragments $(0.72$ and $0.83 \mathrm{bp}$ ) generated by all $P$. brasiliensis strains so far studied, when they are subjected to RAPD, using OPG18 (Operon) as the primer of choice [50]. One pair from the $0.72 \mathrm{bp}$ fragment

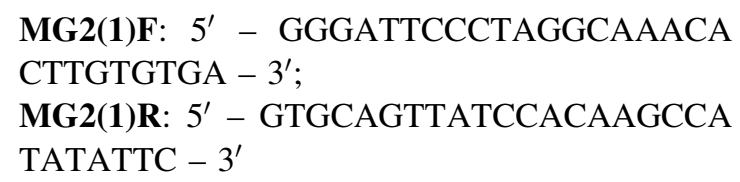

was specific for $P$. brasiliensis, and detected as little as $10 \mathrm{pg}$ of fungal DNA [74]. These primers produced positive identification bands in patients with a confirmed diagnosis of chronic PCM (Fig. 4). Inter-

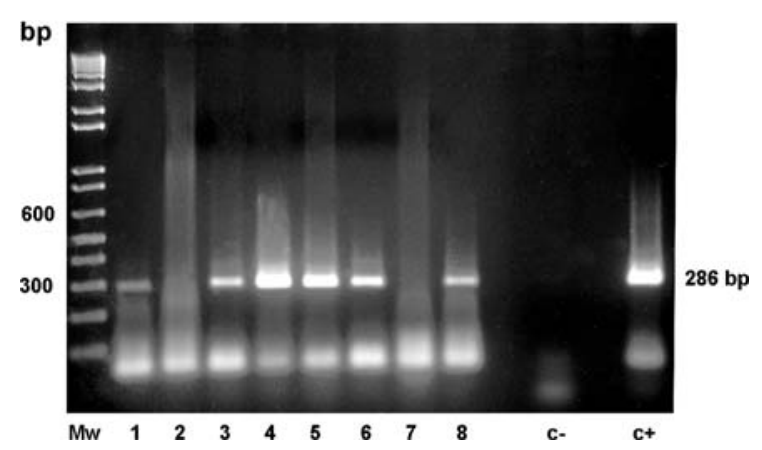

Fig. 4 Identification of $P$. brasiliensis DNA by reamplification with primers MG2(1)F/MG2(1)R of clinical samples from paracoccidioidomycosis patients. Mw, standard; 1-7: sputum samples, and 8: CSF sample; $\mathrm{c}^{-}$, negative control; $\mathrm{c}+$, P. brasiliensis DNA [74]. Reproduced by permission

estingly, in two cases of suspected relapses (patients 6 and 7, Fig. 4), our molecular test produced results that preceded by two or more weeks, subsequent data obtained by clinical, serological or mycological tests. One of them (patient 6) turned out to be a PCM relapse, while the other one (patient 7) was not, as correctly predicted by the molecular test. As for patient 8 , he suffered from chronic multifocal PCM, and developed neurological symptoms of impairment, suggestive of an involvement of the central nervous system (CNS). Treatment with amphotericin B receded mucosal lesions, but not the CNS impairment. Our molecular test was able to detect $P$. brasiliensis in a cerebrospinal fluid (CSF) sample from this patient, although antibody detection and microscopic observation were negative for the presence of the fungus in this sample, as usually reported in CNS-PCM [75].

\section{Final remarks}

Recently, research on PCM and its causal agent, $P$. brasiliensis, has enjoyed a fast growth with the introduction of molecular and chemical tools, opening new roads for a better understanding of this health problem that affects the rural population of Latin America. It is hoped that continuous progress in the area will help in the development of new methods for the prevention, detection, and cure of the disease.

\section{References}

1. Berman J. Morphogenesis and cell cycle progression in Candida albicans. Curr Opin Microbiol 2006;9:595-601. 
2. Momany M. Growth control and polarization. Med Mycol 2005;43(Suppl 1):S23-5.

3. San-Blas G, Niño-Vega G, Iturriaga T. Paracoccidioides brasiliensis and paracoccidioidomycosis: molecular approaches to morphogenesis, diagnosis, epidemiology, taxonomy and genetics. Med Mycol 2002;40:225-42.

4. Wanke B, Londero AT. Epidemiology and paracoccidioidomycosis infection. In: Franco M, Lacaz CS, RestrepoMoreno A, Del Negro G, editors. Paracoccidioidomycosis. Boca Raton: CRC Press; 1994. p. 109-20.

5. Shikanai-Yasuda MA, Queiroz-Telles F, Mendes RP, Colombo AL, Moretti ML. Consenso em paracoccidioidomicose. Rev Soc Bras Med Trop 2006;39:297-310.

6. San-Blas G, Niño-Vega G. Morphogenesis of agents of endemic mycoses. In: San-Blas G, Calderone R, editors. Pathogenic fungi: structural biology and taxonomy, chapter 5. Caister Wymondham, Norfolk: Academic Press; 2004. p. 167-220.

7. Klis FM, Mol P, Hellingwerf K, Brul S. Dynamics of cell wall structure in Saccharomyces cerevisiae. FEMS Microbiol Rev 2002;26:239-56.

8. Lesage G, Bussey H. Cell wall assembly in Saccharomyces cerevisiae. Microbiol Mol Biol Rev 2006;70:317-47.

9. Bartnicki-Garcia S. Cell wall chemistry, morphogenesis and taxonomy of fungi. Annu Rev Microbiol 1968;22: 87-108.

10. Roncero C. The genetic complexity of chitin synthesis in fungi. Curr Genet 2002;41:367-78.

11. Munro CA, Gow NAR. Chitin synthesis in human pathogenic fungi. Med Mycol 2001;39:41-53.

12. Odds FC, Brown AJP, Gow NAR. Antifungal agents: mechanisms of action. Trends Microbiol 2003;11:272-9.

13. Kanetsuna F, Carbonell LM, Moreno RE, Rodriguez J. Cell wall composition of the yeast and mycelial forms of Paracoccidioides brasiliensis. J Bacteriol 1969;97:1036-41.

14. Kanetsuna F, Carbonell LM, Azuma I, Yamamura Y. Biochemical studies on the thermal dimorphism of Paracoccidioides brasiliensis. J Bacteriol 1972;110:208-18.

15. San-Blas G, San-Blas F, Serrano LE. Host-parasite relationships in the yeastlike form of Paracoccidioides brasiliensis strain IVIC Pb9. Infect Inmun 1977;15:343-6.

16. Manners DJ, Meyer MT. The molecular structures of some glucans from the cell walls of Schizosaccharomyces pombe. Carbohydr Res 1977;57:189-203.

17. Zonneveld BJM. Morphogenesis in Aspergillus nidulans. The significance of a $\alpha$-1,3-glucan of the cell wall and $\alpha$-1,3-glucanase for cleistothecium development. Biochim Biophys Acta 1972;273:174-187.

18. Horisberger M, Lewis BA, Smith F. Structure of a (1-3)alpha-D-glucan (pseudonigeran) of Aspergillus niger NNRL 326 cell wall. Carbohydr Res 1972;23:183-8.

19. Fontaine T, Simenel C, Dubreucq G, Adam O, Delepierre M, Lemoine J, et al. Molecular organization of the alkaliinsoluble fraction of Aspergillus fumigatus cell wall. J Biol Chem 2000;275:27594-607.

20. Reese AJ, Doering TL. Cell wall alpha-1,3-glucan is required to anchor the Cryptococcus neoformans capsule. Mol Microbiol 2003;50:1401-9.

21. James PG, Cherniak R, Jones RG, Stortz CA, Reiss E. Cell-wall glucans of Cryptococcus neoformans Cap 67. Carbohydr Res 1990;198:23-38.
22. Hogan LH, Klein BS. Altered expression of surface alpha1,3-glucan in genetically related strains of Blastomyces dermatitidis that differ in virulence. Infect Inmmun 1994;62:3543-6.

23. Grün $\mathrm{CH}$, Hochstenbach F, Humbel BM, Verkleij AJ, Sietsma JH, Klis FM, et al. The structure of cell wall $\alpha$-glucan from fission yeast. Glycobiology 2005;15:245-57.

24. Hochstenbach F, Klis FM, van den Ende H, van Donselaar E, Peters PJ, Klausner RD. Identification of a putative alpha-glucan synthase essential for cell wall construction and morphogenesis in fission yeast. Proc Natl Acad Sci USA 1998;95:9161-6.

25. Katayama S, Hirata D, Arellano M, Pérez P, Toda T. Fission yeast $\alpha$-glucan synthase Mok1 requires the actin cytoskeleton to localize the sites of growth and plays an essential role in cell morphogenesis downstream of protein kinase C function. J Cell Biol 1999;144:1173-86.

26. Damveld RA, van Kuyk PA, Arentshorst M, Klis FM, van den Hondel CAMJJ, Ram AFJ. Expression of agsA, one of five 1,3- $\alpha$-D-glucan synthase-encoding genes in Aspergillus niger, is induced in response to cell wall stress. Fungal Genet Biol 2005;42:165-77.

27. Henrissat B. A classification of glycosyl hydrolases based on amino acid sequence similarities. Biochem $\mathbf{J}$ 1991;280:309-16.

28. Ruiz-Herrera J, González-Prieto JM, Ruiz-Medrano R. Evolution and phylogenetic relationships of chitin synthase from yeast and fungi. FEMS Yeast Res 2002;1:247-56.

29. Niño-Vega GA, Carrero L, San-Blas G. Isolation of the CHS4 gene of Paracoccidioides brasiliensis and its accomodation in a new class of chitin synthases. Med Mycol 2004;42:51-7.

30. Mandel MA, Galgiani JN, Kroken S, Orbach MJ. Coccidioides posadasii contains single chitin synthase genes corresponding to classes I to VII. Fungal Genet Biol 2006;43:775-88.

31. Niño-Vega GA, Buurman ET, Gooday GW, San-Blas G, Gow NAR. Molecular cloning and sequencing of a chitin synthase gene (CHS2) of Paracoccidioides brasiliensis. Yeast 1998;14:181-7.

32. Niño-Vega GA, Munro CA, San-Blas G, Gooday GW, Gow NAR. Differential expression of chitin synthase genes during temperature-induced dimorphic transitions in Paracoccidioides brasiliensis. Med Mycol 2000;38:31-9.

33. Tomazett PK, Cruz AH, Bonfim SM, Soares CM, Pereira M. The cell wall of Paracoccidioides brasiliensis: insights from its transcriptome. Genetics Mol Res 2005;4: 309-325.

34. San Blas G, San Blas F. Biochemistry of Paracoccidioides brasiliensis dimorphism. In: Franco M, Lacaz C, RestrepoMoreno A, Del Negro, A, editors. Paracoccidioidomycosis. Boca Raton, Florida: CRC Press; 1994. p. 49-66.

35. Leclerc MC, Phillipe H, Guého E. Phylogeny of dermatophytes and dimorphic fungi based on large subunit ribosomal RNA sequence comparisons. J Med Vet Mycol 1994;32:331-41.

36. Niño-Vega G, Pérez-Silva C, San-Blas G. The actin gene in Paracoccidioides brasiliensis: organization, expression and phylogenetic analyses. Mycol Res 2007;111:363-9.

37. Kwon-Chung KJ. Emmonsiella capsulata: perfect state of Histoplasma capsulatum. Science 1972;177:368-9. 
38. Torres-Guzmán JC, Xoconostle-Cazares B, GuevaraOlvera L, Ortiz L, San-Blas G, Domínguez A, et al. Comparison of fungal ornithine decarboxylases. Curr Microbiol 1996;33:390-2.

39. Niño-Vega GA, Sorais F, Calcagno AM, Ruiz-Herrera J, Martínez-Espinoza AD, San-Blas G. Cloning and expression analysis of the ornithine decarboxylase gene (PbrODC) of the pathogenic fungus Paracoccidioides brasiliensis. Yeast 2004;21:211-8.

40. Bowman BH, White TJ, Taylor JW. Human pathogenic fungi and their close nonpathogenic relatives. Mol Phylogenet Evol 1996;6:89-96.

41. Peterson SW, Sigler L. Molecular genetic variation in Emmonsia crescens and Emmonsia parva, etiologic agents of adiaspiromycosis, and their phylogenetic relationship to Blastomyces dermatitidis (Ajellomyces dermatitidis) and other systemic fungal pathogens. J Clin Microbiol 1998;36:2918-25.

42. Bialek R, Ibricevic A, Aepinus C, Najvar LK, Fothergill AW, Knobloch J, et al. Detection of Paracoccidioides brasiliensis in tissue samples by a nested PCR assay. J Clin Microbiol 2000;38:2940-2.

43. Leal JA, Prieto A, Ahrazem O, Pereyra T, Bernabé M. Cell wall polysaccharides: Characters for fungal taxonomy and evolution. Rec Res Develop Microbiol 2001;5:235-48.

44. Prieto A, Ahrazem O, Bernabé M, Leal JA. Polysaccharides F1SS. Taxonomic and evolutionary characters for ascomycetes. In: San-Blas G, Calderone R, editors. Pathogenic fungi: structural biology and taxonomy, chapter 10 . Wymondham, Norfolk: Caister Academic Press; 2004. p. 319-60.

45. Prieto A, Ahrazem O, San-Blas G, Leal JA, JiménezBarbero J, Bernabé M. Structural differences between the alkali-extracted water-soluble cell wall polysaccharides from mycelial and yeast phases of the pathogenic dimorphic fungus Paracoccidioides brasiliensis. Glycobiology 2003;13:743-7.

46. San-Blas G, Prieto A, Bernabé M, Ahrazem O, Moreno B, Leal JA. $\alpha$-Galf $1 \rightarrow 6-\alpha$-mannopyranoside side chains in Paracoccidioides brasiliensis cell wall are shared by members of the Onygenales, but not by galactomannans of other fungal genera. Med Mycol 2005;43:153-9.

47. Fisher MC, Koenig GL, White TJ, Taylor JW. Molecular and phenotypic description of Coccidioides posadasii sp. nov., previously recognized as the non-Californian population of Coccidioides immitis. Mycologia 2002;94:73-84.

48. Taylor JW, Fisher MC. Fungal multilocus sequence typing-it's not just for bacteria. Curr Op Microbiol 2003;6:351-6.

49. Kasuga T, White TJ, Koenig G, McEwen J, Restrepo A, Castaneda E, et al. Phylogeography of the fungal pathogen Histoplasma capsulatum. Mol Ecol 2003;12:3383-401.

50. Calcagno AM, Niño-Vega G, San-Blas F, San-Blas G. Geographic discrimination of Paracoccidioides brasiliensis strains by randomly amplified polymorphic DNA analysis. J Clin Microbiol 1998;36:1733-6.

51. Molinari-Madlum EEWI, Felipe MSS, Soares CMA. Virulence of Paracoccidioides brasiliensis isolates can be correlated to groups defined by random amplified polymorphic DNA analysis. Med Mycol 1999;37: 269-76.
52. Soares CM, Madlun EE, da Silva SP, Pereira M, Felipe MS. Characterization of Paracoccidioides brasiliensis isolates by random amplified polymorphic DNA analysis. $\mathbf{J}$ Clin Microbiol 1995;33:505-7.

53. Niño-Vega G, Calcagno AM, San-Blas G, San-Blas F, Gooday GW, Gow NAR. RFLP analysis reveals marked geographical isolation between strains of Paracoccidioides brasiliensis. Med Mycol 2000;38:437-41.

54. Hebeler-Barbosa F, Morais FV, Montenegro MR, Kuramae EE, Montes B, McEwen JG, et al. Comparison of the sequences of the internal transcribed spacer regions and PbGP43 genes of Paracoccidioides brasiliensis from patients and armadillos (Dasypus novemcinctus). J Clin Microbiol 2003;41:5735-7.

55. Morais FV, Barros TF, Fukada MK, Cisalpino PS, Puccia R. Polymorphism in the gene coding for the immunodominant antigen gp43 from the pathogenic fungus Paracoccidioides brasiliensis. J Clin Microbiol 2000;38:3960-6.

56. Carvalho KC, Ganiko L, Batista WL, Morais FV, Marques ER, Goldman GH, et al. Virulence of Paracoccidioides brasiliensis and gp43 expression in isolates bearing known PbGP43 genotype. Microb Infect 2005;7:55-65.

57. Matute DR, McEwen JG, Puccia R, Montes BA, San-Blas G, Bagagli E, Rauscher JT, Restrepo A, Morais F, Niño-Vega G, Taylor JW. Cryptic speciation and recombination in the fungus Paracoccidioides brasiliensis as revealed by gene genealogies. Mol Biol Evol 2006;23: 65-73.

58. Felipe MSS, Andrade RV, Arraes FBM, Nicola AM, Maranhão AQ, Torres FAG, et al Transcriptional profiles of the human pathogenic fungus Paracoccidioides brasiliensis in mycelium and yeast cells. J Biol Chem 2005;280:24706-14.

59. Visbal G., San-Blas G, Murgich J, Franco H. Paracoccidioides brasiliensis, paracoccidioidomycosis, and antifungal antibiotics. Curr Drug Targets: Infect Disord 2005;5:211-26.

60. Visbal G, Alvarez A, Moreno B, San-Blas G. Inhibitors of (S)-adenosyl-1-methionine: $\Delta^{24}$ - sterol methyl transferase and $\Delta^{24(28)}$-sterol methyl reductase as possible antifungal agents against Paracoccidioides brasiliensis. Antimicrob Agents Chemother 2003;47:2966-70.

61. Urbina JA, Vivas J, Visbal G, Contreras LM. Modification of the sterol composition of Trypanosoma (Schizotrypanum) cruzi epimastigotes by $\Delta^{(24,25)}$ sterol methyl transferase inhibitors and their combination with ketoconazole. Mol Biochem Parasitol 1995;73:199-210.

62. Urbina JA, Visbal G, Contreras LM, McLaughlin G, Docampo R. Inhibitors of $\Delta^{(24,25)}$ sterol methyl transferase block sterol synthesis and cell proliferation in Pneumocystis carinii. Antimicrob Agents Chemother 1997;41: 1428-32.

63. San-Blas G, Urbina JA, Marchán E, Contreras LM, Sorais F, San-Blas F. Inhibition of Paracoccidioides brasiliensis by ajoene is associated with blockade of phosphatidylcholine biosynthesis. Microbiology 1997;143:1583-6.

64. Pfaller MA, Marco M, Messer SA, Jones RN. In vitro activity of two echinocandin derivatives, LY303366 and MK-0991 (L-743,792), against clinical isolates of Aspergillus, Fusarium, Rhizopus, and other filamentous fungi. Diagn Microbiol Infect Dis 1998;30:251-255. 
65. Espinel-Ingroff A. Comparison of in vitro activities of the new triazole SCH56592 and the echinocandins MK-0991 (L-743,872) and LY303366 against opportunistic filamentous and dimorphic fungi and yeasts. J Clin Microbiol 1998;36:2950-6.

66. Cantón E, Pemán J, Gobernado M, Alvarez E, Baquero F, Cisterna R, et al. Sensititre yeastone caspofungin susceptibility testing of Candida clinical isolates: correlation with results of NCCLS M27-A2 multicenter study. Antimicrob Agents Chemother 2005;49:1604-7.

67. Odds FC, Motyl M, Andrade R, Bille J, Canton E, CuencaEstrella M, et al. Interlaboratory comparison of results of susceptibility testing with caspofungin against Candida and Aspergillus species. J Clin Microbiol 2004;42:3475-82.

68. Nakai T, Uno J, Ikeda F, Tawara S, Nishimura K, Miyaji M. In vitro antifungal activity of micafungin (FK463) against dimorphic fungi: comparison of yeast-like and mycelial forms. Antimicrob Agents Chemother 2003;47:13761381.

69. Mendes-Giannini MJS, Bueno JP, Shikanai-Yashuda MA, Ferreira AW, Masuda A. Detection of 43,000-molecularweight glycoprotein in sera of patients with paracoccidioidomycosis. J Clin Microbiol 1989;27:2842-5.

70. Del Negro GMB, Benard G, Assis CM, Vidal MS, Garcia NM, Otani C, et al. Lack of reactivity of paracoccidioid- omycosis sera in the double immunodiffusion test with the gp43 antigen: report of two cases. J Med Vet Mycol 1995;33:113-6.

71. Puccia R, Travassos LR. 43-Kilodalton glycoprotein from Paracoccidioides brasiliensis: immunological reactions with sera from patients with paracoccidioidomycosis, histoplasmosis and Jorge Lobo disease. J Clin Microbiol 1991;29:1610-5.

72. Imai T, Sano A, Miyami Y, Watanabe K, Aoki FH, Branchini ML, et al. A new PCR primer for the identification of Paracoccidioides brasiliensis based on rRNA sequences coding the internal transcribed spacers (ITS) and 5.8s regions. Med Mycol 2000;38:323-6.

73. Gomes GM, Cisalpino PS, Taborda CP, Camargo ZP. PCR for diagnosis of paracoccidioidomycosis. J Clin Microbiol 2000;38:3478-80.

74. San-Blas G, Niño-Vega G, Barreto L, Hebeler-Barbosa F, Bagagli E, Olivero de Briceño R, et al. Primers for the clinical detection of Paracoccidioides brasiliensis. J Clin Microbiol 2005;49:4255-7.

75. Almeida SM, Queiroz-Telles F, Teive HAG, Ribeiro CEL, Werneck LC. Central nervous system paracoccidioidomycosis: clinical features and laboratorial findings. J Infect 2004;48:193-8. 